\title{
Bacteriological Assessment of Drinking Water Sources in Imo State, Nigeria
}

\author{
C.C. Iwuala ${ }^{1}$, I.N.S. Dozie ${ }^{1}$, O.G. Udujih ${ }^{1}$, H.I. Udujih ${ }^{2}$, \\ S.N. Okereke ${ }^{1}$ and O.E. Okonkwo ${ }^{3}$ \\ ${ }^{\text {I}}$ Federal University of Technology Owerri, Imo State, Nigeria \\ ${ }^{2}$ Imo State University Owerri, Imo State, Nigeria \\ ${ }^{3}$ Ministry of Health Imo State, Nigeria \\ *Corresponding author
}

\section{A B S T R A C T}

\section{Keywords \\ Bacteria, Drinking water, Nigeria \\ Article Info \\ Accepted: \\ 04 November 2019 \\ Available Online: \\ 10 December 2019}

\begin{abstract}
Drinking water sources in the three geopolitical zones; Owerri, Orlu and Okigwe zones of Imo state, Nigeria were assessed using standard bacteriological techniques to determine their bacterial profile and counts. The result showed that the levels of bacterial counts were high compared to the recommended standard of the World Health Organization. The total bacterial count was found to be very high with an average count of $487.58 \mathrm{CFU} / 100 \mathrm{ml}$. Okigwe zone had the lowest count for all the microorganisms assessed while Owerri zone showed higher counts than Orlu zone in most of the organisms encountered except on total feacal count. This study has highlighted the need for urgent intervention in the provision of potable water for domestic consumption in Imo State.
\end{abstract}

\section{Introduction}

Water is considered to be the second most essential need of all life (man, animals, plants and microorganisms), after air. It forms twothirds of the human body. It is formed by the bonding of one atom of oxygen to two atoms of hydrogen (DWSQC, 2000; USGS, 2004). Water-borne diseases are those diseases which occur when water contaminated particularly by pathogens from human excreta are consumed. Worldwide, the lack of sanitary waste disposal and lack of clean water for drinking, cooking and washing can be identified as the cause of over 12 million deaths annually (Davidson et al., 1992); USAID, 1990). Water-borne diseases include cholera, typhoid, shigella, polio, meningitis, and hepatitis A and E, amoebic and bacillary dysentery, plus over 30 species of parasites that infect human intestines, of which seven are globally distributed and cause serious illnesses such as amoebiasis, giardiasis, taeniasis, ascariasis, trichuriasis, strongyloidiasis, etc.

Human beings and animals can act as host to the bacterial, viral and protozoan organisms that cause these diseases. Millions of people have little access to sanitary waste disposal or 
to clean water for personal hygiene. An estimated 3 billion people lack a sanitary toilet. For example over 1.2 billion people are at risk because they lack access to fresh water (Osunwa, 2011; Khan, 1997; UN, 1997; Warner, 1998; WHO, 1997).

Where proper sanitation facilities are lacking, water-borne diseases have the propensity to spread rapidly. Untreated excreta carrying disease organisms wash or leak into freshwater sources, contaminating drinking water and food. The extent to which disease causing organisms occur in specific freshwater depends on the amount of human and animal excreta that they contain (Bauman, 1994).

\section{Materials and Methods}

\section{Study area}

The area of study is Imo State. The state is named after the Imo river. The geo-political zones in Imo State are Okigwe, Orlu and Owerri. It has Owerri as it capital and largest city. Situated in South Eastern Nigeria, and covering an area of 5,530 square kilometres. Imo State derives its name from Imo River, which takes its course from the Okigwe/Awka upland. It lies within latitudes $4^{\circ} 45^{\prime} \mathrm{N}$ and $7^{\circ} 15^{\prime} \mathrm{N}$, and longitude $6^{\circ} 50^{\prime} \mathrm{E}$ and $7^{\circ} 25^{\prime} \mathrm{E}$. Imo State has many rivers. The main rivers in the state are Imo, Otamiri and Njaba. The major lakes are in Oguta and Abadaba in Obowu Local Government Area.

\section{Sample collection and analysis}

Water samples used for this study were collected from the different water sources (Rivers, Streams, Lakes, Springs, Rainwater, Tap-water, Boreholes, Storage Tanks, Mosques etc.) available in the selected study areas. Thirty eight Water samples, with an average of 12 water samples per zone were collected.
Water samples were collected in 1-litre sterile bottles and plastic cans and processed according to the standard of Baker (1971), Cruickshank et al., (1975), NWRI (1997), Cheesebrough (2004), and transported to the laboratory for analyses. Samples were transported in ice-packs and ice-boxes where delays were envisaged.

Samples were assessed bacteriologically by Membrane Filtration Technique (MFT), using $0.45 \mathrm{~nm}$ and $0.65 \mathrm{~nm}$ for bacteria respectively (Cheesebrough, 2004). Total heterotrophic counts (bacterial counts), total coliform counts and more specifically, Escherichia coli counts for each water sample for samples from the Boreholes, Run-off from ablution, Streams and rivers, and wells where residents washed, bathed and defecated, were determined.

\section{Results and Discussion}

The assessment for microbial organisms contained in water samples taken from the drinking water sources in Imo State, Nigeria indicated that that there were several bacterial counts observed in the water samples. Clearly, the levels of bacterial counts were observed to be quite high on each of the microbial organism assessed, in comparison with the recommended standard of the World Health Organization (WHO).

The highest of the microorganisms found in the water samples in Imo state was the total bacteria count with the average count of $487.58 \mathrm{cfu} / 100 \mathrm{ml}$, at a standard deviation of $908.40 \mathrm{cfu} / 100 \mathrm{ml}$ for the bacteria count. Total coliform was also found to be very high with an average count of $324.66 \mathrm{cfu} / 100 \mathrm{ml}$ (Owerri zone $=585.36 \mathrm{cfu} / 100 \mathrm{ml}$, Okigwe zone $=$ $27.86 \mathrm{cfu} / 100 \mathrm{ml}$ and Orlu zone $=391.21$ $\mathrm{cfu} / 100 \mathrm{ml})$. 
Table.1 Average count for microbial organisms in water samples in Imo state

\begin{tabular}{|c|c|c|c|c|c|c|c|c|c|c|}
\hline \multirow[b]{2}{*}{ Parameters } & \multirow{2}{*}{$\begin{array}{c}\text { WHO } \\
\text { Standard }\end{array}$} & \multicolumn{2}{|c|}{ OWERRI } & \multicolumn{2}{|c|}{ OKIGWE } & \multicolumn{2}{|c|}{ ORLU } & \multicolumn{2}{|c|}{ TOTAL } & \multirow{2}{*}{$\begin{array}{c}\text { Sig } \\
\text { p-value }\end{array}$} \\
\hline & & Average & Std. Dev & Average & Std. Dev & Average & Std. Dev & Average & Std. Dev & \\
\hline $\begin{array}{l}\text { Total Faecal Count, } \\
\text { cfu/100ml }\end{array}$ & 0 & 153.727 & 365.042 & 19.857 & 29.573 & 203.143 & 362.608 & 127.079 & 297.877 & 0.160 \\
\hline $\begin{array}{l}\text { Total E.coli Count, } \\
\text { cfu/100ml }\end{array}$ & 0 & 59.364 & 117.699 & 8.857 & 17.978 & 87.571 & 152.070 & 52.816 & 114.443 & 0.103 \\
\hline $\begin{array}{l}\text { Total } \\
\text { Staphylococcus } \\
\text { aureus count, } \\
\text { cfu/100ml }\end{array}$ & 0 & 83.272 & 120.773 & 17.786 & 18.861 & 50.071 & 69.126 & 49.947 & 79.655 & 0.113 \\
\hline $\begin{array}{l}\text { Total Bacteria } \\
\text { count, cfu/100ml }\end{array}$ & 30 & 876.636 & 1326.793 & 102.5 & 196.077 & 530.857 & 828.055 & 487.579 & 908.395 & 0.079 \\
\hline $\begin{array}{l}\text { Total coliforn } \\
\text { count, cfu/ } 100 \mathrm{ml}\end{array}$ & 0 & 585.364 & 897.710 & 27.857 & 17.150 & 391.214 & 650.702 & 324.658 & 646.974 & 0.064 \\
\hline $\begin{array}{l}\text { Total Salmonella } \\
\text { Shigella } \\
\text { cfu/100ml }\end{array}$ & 0 & 194.727 & 438.614 & 29.571 & 61.362 & 120.714 & 247.223 & 112.316 & 281.012 & 0.311 \\
\hline $\begin{array}{l}\text { Total Fungicount, } \\
\text { cfu/100ml }\end{array}$ & 0 & 241.2 & 528.967 & 16.857 & 17.4526 & 54.6428 & 115.823 & 92.459 & 289.067 & 0.151 \\
\hline $\begin{array}{l}\text { WHO Vs Average } \\
\text { (Total) }\end{array}$ & & & & p-valu & $17, \mathrm{t}$ & $78, \mathrm{df}=$ & & & & \\
\hline
\end{tabular}


Figure.1 Line graph for the average count for microbial organisms in water samples in the zones of Imo state along with WHO standard

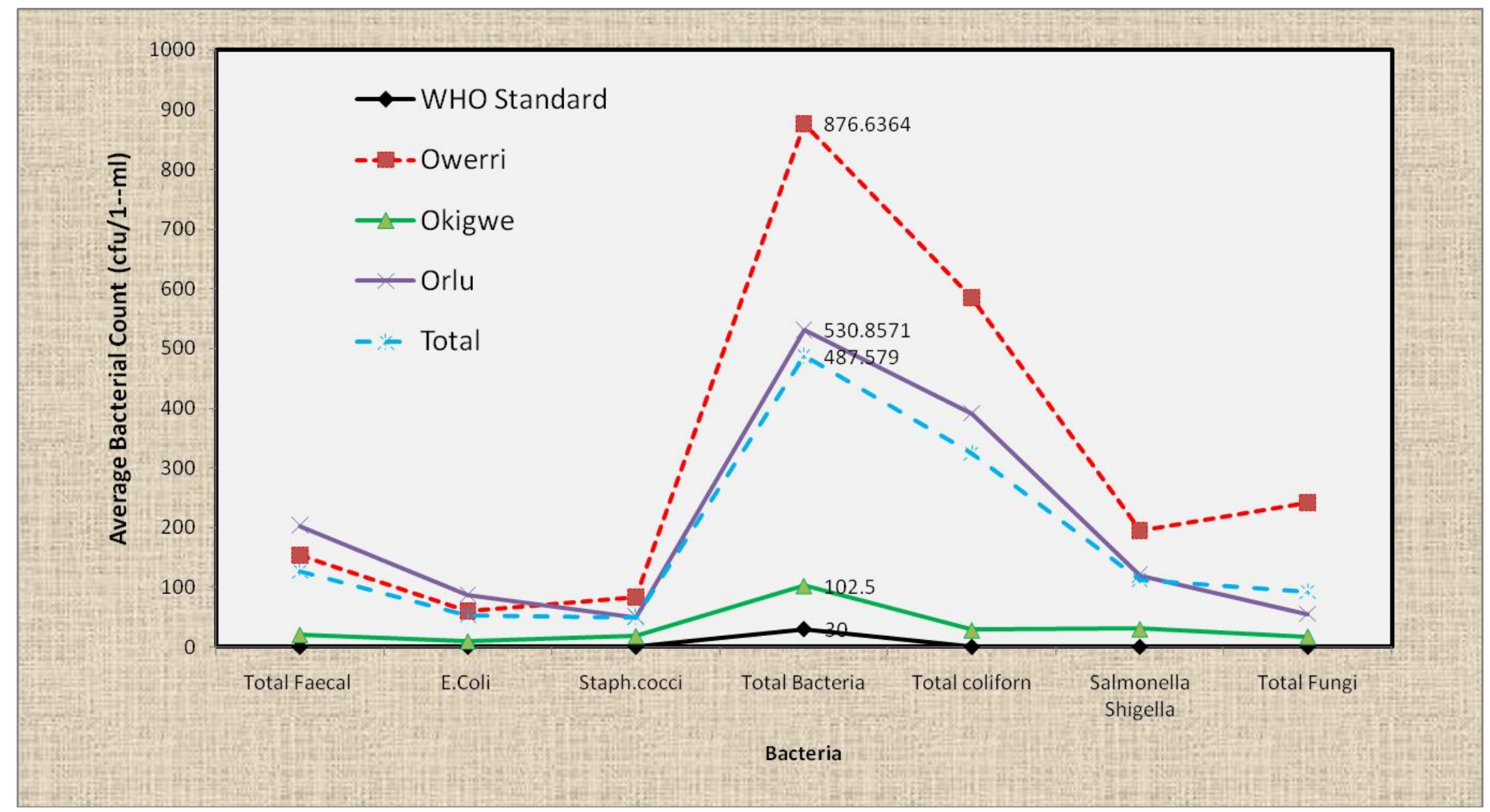


The lowest count found in water samples was in the test for Staphylococcus species with an overall mean count of $49.95 \mathrm{cfu} / 100 \mathrm{ml}(83.27$ $\mathrm{cfu} / 100 \mathrm{ml}$ in Owerri zone, $17.79 \mathrm{cfu} / 100 \mathrm{ml}$ in Okigwe zone $=$ and $50.07 \mathrm{cfu} / 100 \mathrm{ml}$ in Orlu zone). Table 1 shows the average count for each micro-organism tested and the corresponding standard deviations for Imo state (total) and for each of the three zones of the state.

Okigwe zone had the lowest count for all the microorganisms assessed, while the Owerri zone showed higher count than the Orlu zone in most of the organisms (Figure 1). The Orlu zone was only higher than the Owerri zone on total faecal count (Orlu zone = 203.14cfu/100ml, Owerri zone $=153.73$ cfu $/ 100 \mathrm{ml}$ ) and for E.coli (Orlu zone $=87.57 \mathrm{cfu} / 100 \mathrm{ml}$, Owerri zone $=52.82$ $\mathrm{cfu} / 100 \mathrm{ml})$

While the minimum tolerance level by the WHO standard for the total bacterial count is $30 \mathrm{cfu} / 100 \mathrm{ml}$, the overall average total bacterial count found in Imo state was (487.58 cfu/100ml), which is far above the WHO standard. However, the average total bacterial count was highest in water samples from Owerri zone $(876.65 \mathrm{cfu} / 100 \mathrm{ml})$, while it was lowest in Okigwe zone water samples (102.5 cfu/100ml). On average, the test on samples from Orlu zone recorded the total bacterial count of cfu/100ml in the water samples taken from the zone.

Statistical test at 5\% significant level shows that significant difference was found between the level of bacteria count found in Imo state and the WHO tolerance standard with probability values ( $\mathrm{p}$ - value) of 0.017 (which is less than 0.05). On the other hand, no significant difference was found among the three zones of Imo state on the count for each of the microorganisms (all p-values were not less than 0.05).
The result indicates that Serratia spp was positive on VP, catalase, urease, citrate, indole, gas and glucose, which in all gives the rate of Serratia spp found in Imo state as 35\%. Similar result was found for Salmonella spp, Klebsiella spp, Enterobacter spp (all at 35\% each). They were found to be $41 \%$ each on Proteus spp and Escherichia coli, and $47 \%$ for Citrobacter spp respectively (Table 2).

At Okigwe zone, $14(93 \%)$ out of 15 water samples taken tested positive for the bacteria. Each of the microorganisms was found positive in all except at one water source. The result on table 3 shows that the only source not found positive is the Paddies Sachet Water.

There were $10(83.3 \%)$ out of 12 positive loadings for each of the microorganisms for the water samples taken at Orlu zone. The only two that were found to be free from bacteria were the Borehole Okporo Orlu and the Borehole Orlu.

For Owerri zone, all the 11 water samples taken tested positive for the bacterial load. Table 6 indicates that the bacterial load for the water samples were $100 \%$ for each of the microorganism.

\section{References}

Baker, F.J, Siverton R.E. \& Pallister C.J (1998); Introduction to Medical Laboratory Technology (17 ${ }^{\text {th }}$ Edition). Butterworths and Heinemann Co. Ltd 251-324

Cheesebrough, M. (2004): Medical Laboratory Manual for Tropical Countries (Volume II), Microbiology (Low Price Edition). Butterworth and Heinemann Ltd., Jordan Hill 200-206

Chikwendu B. (2008): The Microbiological and Physico-chemical Qualities of Otamiri River in the Dry Season. Book 
of Abstracts, Nigeria Society for Microbiology, $32^{\text {nd }}$ Annual Conference, $A B S U\left(13^{\text {th }}-17^{\text {th }}\right.$ October, 2008) 11.

Cruikshank R., Duguid, J.P. and Swain R.H.A (1975): Medical Microbiology $\left(12^{\text {th }}\right.$ Edition) Volume 2: The Practice of Medical Microbiology - Churchill and Livingstone Edinburgh, London and New York 275-300, 367-370

Ejechi B.O, Olobaniyi S.B, Ogban F.E, Ugbe F.C (2007): Physical and Sanitary Quality of Hand Dug Well-water from Oil-producing Area of Nigeria: Journal of Environmental Monitoring Assessment 128(13): 495-510.

Khan, A.H. (1997): The Sanitation Gap: Development Deadly Menace. In the Progress of Nation New York UNICEF 5-13.

National Water Resources Institute (NWRI) (1997): Training Guidelines for Water Quality Testing and Control, Outreach Department, Mando Road, Kaduna 8-62

Oasisdesign (2003): Water Quality Control www.oasisdesign.net

Oasisdesign (2009): Fecal Coliform Bacteria www.oasisdesign.net

Oasisdesign (2004): Fecal Coliform Measurements www.oasisdesign.net

Ogan, M.T. (1989): Magnitude of Faecal Contamination of Rural Community well water in Nigeria and its Relationship of Well and Water Properties; Zentrabl Hyg Unweltmed 189(3): 279-283.

Okereke J.N (2009): Qualitative Studies of water from Different Sources and the Distribution of Water related Diseases in Imo State, Nigeria Unpublished
Ph.D. Thesis, Federal University of Technology (FUTO), Owerri, 256 pages.

Okereke, J. N., Obasi, K.O Obiekezie, S.O. and Okechukwu, R. I (2006): Bacterial Quality of Rainwater in Selected Communities in Imo State, Nigeria; Estud Biologie 28(63): 51 -59.

Osunwa, Chidinma O. (2011): Water Utilization and its Health Implications in Riverine Areas, Imo State Unpublished $\mathrm{PhD}$ Thesis, Imo State University, Owerri. Imo State, 335 pages.

United Nations (1997): Commission on Sustainable development. Comprehensive Assessment of Freshwater Resources of the World. Report of the Secretary General, New York 39 pages.

United States Agency for International Development (USAID) (1990): Strategies for Linking Water and Sanitation Programmes to Child Survival. Washington D.C. USAID, September 190 1-62.

USGS (2004): The Effects of Urbanization on Water Quality; How Urbanization Affects the Hydrological Systems.

Warner, D. (1998): Drinking Water Supply and Environmental Sanitation for Health. Presented at the International Conference of Water and Sustainable Development, Paris. 19-21 March 1-10

World Health Organization (1997): Health and Environment in Sustainable Development Five Years after the Earth Summit. Geneva 19-133.

\section{How to cite this article:}

Iwuala, C.C., I.N.S. Dozie, O.G. Udujih, H.I. Udujih, S.N. Okereke and Okonkwo, O.E. 2019. Bacteriological Assessment of Drinking Water Sources in Imo State, Nigeria. Int.J.Curr.Microbiol.App.Sci. 8(12): 3087-3092. doi: https://doi.org/10.20546/ijcmas.2019.812.359 